\title{
A Case of Eagle's Syndrome after Blunt Neck Trauma
}

\author{
Doo-Ri Kim, Yong-Sug Choi, Joon-Hyun Kim, and Jung-Hae Cho \\ Department of Otorhinolaryngology-Head and Neck Surgery, College of Medicine, The Catholic University of Korea, Seoul, Korea
}

\section{경부 둔상 후 발생한 이글 증후군 1예}

김두리 · 최용석 · 김준현 · 조정해

가톨릭대학교 의과대학 이비인후과학교실

\author{
Received August 6, 2013 \\ Revised September 17, 2013 \\ Accepted September 23, 2013 \\ Address for correspondence \\ Jung-Hae Cho, MD \\ Department of Otorhinolaryngology- \\ Head and Neck Surgery, \\ College of Medicine, \\ The Catholic University of Korea, \\ 93 Jungbu-daero, Paldal-gu, \\ Suwon 442-723, Korea \\ Tel +82-31-249-8306 \\ Fax +82-31-253-3752 \\ E-mail jhchomd@catholic.ac.kr
}

Eagle's syndrome has various symptoms at cervico-facial lesion. Recently, we have experienced a case of Eagle's syndrome that developed after a blunt neck trauma. A 51-year-old man presented with a click sound when he turned his head to the right. The symptom had developed after a traffic accident that occurred 2 months ago. Physical examination revealed a long styloid process that was easily palpable and burging out into the right tonsillar fossa. Radiologic examination did not reveal any presence of fracture on stylohyoid complex including stylohyoid ligament. We underwent a transoral resection of styloid process and released a stylohyoid ligament. The patient immediately experienced a relief of the symptom following the operation. It might be elucidated that the patient had an elongated styloid process and that the neck trauma had developed due to the dislocation or pseudoarticulation between stylohyoid ligament and the hyoid bone. Transoral resection of styloid process released pseudoarticulation and relieved the symptom. Korean J Otorhinolaryngol-Head Neck Surg 2014;57(6):400-2

\section{서 론}

정상 성인에서 경상돌기의 길이는 평균 $2.5 \sim 3 \mathrm{~cm}$ 이나 선천 적 또는 후천적 원인으로 인해 경상돌기가 $3 \mathrm{~cm}$ 이상 연장이 되었을 때 $\mathrm{V}, \mathrm{VII}, \mathrm{IX}, \mathrm{X}$ 뇌신경과 경부 교감신경 등에 자극 을 주어 경부 및 안면부에 통증을 비롯한 다양한 임상 증상 을 유발할 수 있다. 1937년 Eagle ${ }^{1)}$ 이 연장된 경상돌기로 인해 발생하는 이러한 증후군을 이글 증후군(Eagle's syndrome) 또는 이상 경상돌기증이라고 발표하였다. 이글 증후군은 편 측 편도와에 국한된 인두통, 이물감, 연하곤란, 안면통 등을 특징으로 하며 이러한 증상은 두부 회전, 혀의 움직임, 연하 또는 저작시 유발 및 악화될 수 있다. 또한, 개구시 발생하는 관절음의 원인 역시 흔히 발생하는 악관절 이상외에도 비전 형적인 이글 증후군의 증상일 수 있다는 보고가 있었다. ${ }^{2}$ 경 상돌기의 연장 또는 골화의 원인은 현재까지는 불분명하지만 유전적인 원인으로 인한 과다 석회화, 외상, 호르몬, 특히 조기
폐경 등이 영향을 미칠 수 있다는 가설이 제시된 바 있다. ${ }^{3)}$ 저자들은 경부 외상 후 발생한 비전형적인 이글 증후군, 즉 경부 회전시 발생되는 관절음을 경상돌기 절제술을 시행하여 즉각적인 증상의 호전을 보였던 환자를 경험하였기에 문헌고 찰과 함께 보고하는 바이다.

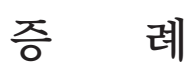

51세 남자 환자가 2개월 전부터 지속되는 경부를 우측으로 회전시 발생되는 관절음을 주소로 내원하였다. 특별한 전신 질환의 병력은 없었으나, 2개월 전 버스를 타고 가는 중 교통 사고로 인한 다발성 안면 골절이 있었다. 이때 비골, 좌측 안 와골 및 좌측 상악골 골절 등에 대하여 성형외과에서 수술 을 시행 받았다. 사고 이전에는 특별한 증상이 없었으나 사고 후 경부 회전시에 주관적으로 느끼는 관절음이 발생되었다 고 하였으나 객관적으로 확인되지는 않았다. 양측 편도는 비 
대칭적으로 우측이 좌측에 비해 돌출되어 있었고, 우측 편도 와에 경상돌기가 돌출되어 쉽게 촉지되었으나 압통은 없었다 (Fig. 1). 단순 경상돌기 촬영 및 경부 전산화단층촬영에서 우 측 경상돌기가 좌측에 비해 비대칭적으로 연장되어 있었으며 우측 편도와 내로 진입되어 있는 것이 관찰되었으나 뚜렷한 골

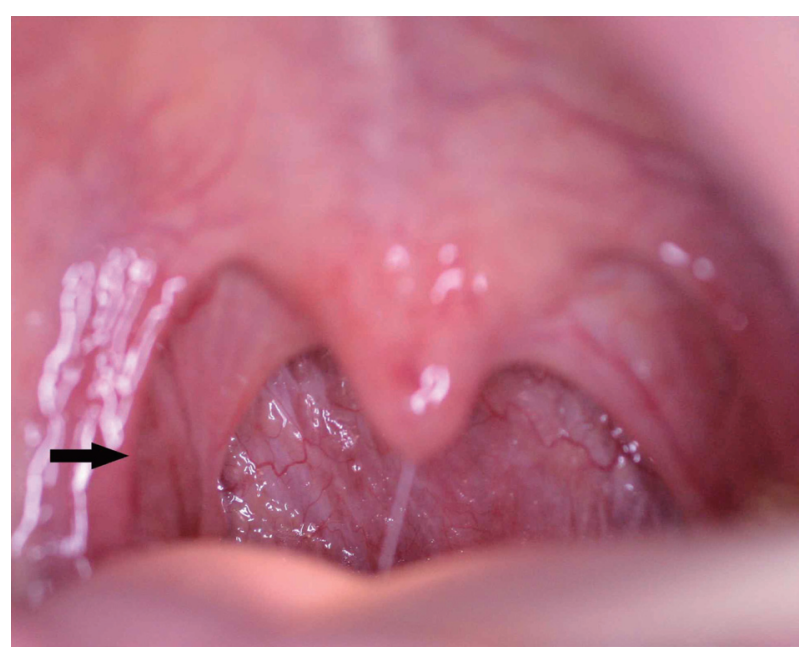

Fig. 1. Peroral photograph showing aymmetric bulging of right tonsil (arrow).
절 소견은 없었다(Fig. 2). 신체 검사 및 영상학적 검사상 이글 증후군을 진단할 수 있었고 진통제 및 근이완제, 항우울제를 투여하며 약 2개월간 경과 관찰하였으나 경부 회전시 유발되는 관절음과 인두 불편감이 지속되어 구강내 접근법으로 우측 경 상돌기 절제술을 계획하였다. 우측 편도선 절제 이후 상인두 수축근을 박리하여 경상설골 인대(stylohyoid ligament)를 쉽 게 확인한 후 경상돌기로부터 분리시키고 경상돌기는 골가위 를 이용하여 $2.5 \mathrm{~cm}$ 정도 절제하였다(Fig. 3). 박리된 상인두 수축근을 다시 봉합한 후 수술을 마쳤다. 수술 직후부터 환자 가 호소하던 우측 경부 회전시 발생되었던 관절음은 완전히 호전되어 환자의 주관적 만족도가 높았으며 특별한 합병증 없이 퇴원하였다. 수술 1년 후 현재 특별히 호소하는 증상 없이 경과 관찰 중이다.

\section{고 찰}

이글 증후군은 매우 드문 질환으로 2005년 Ilgüy 등)이 860 명의 치아 파노라마 촬영을 조사하였던 연구에서 32명만 이 양측 또는 편측의 경상돌기의 연장 또는 경상설골인대의

Fig. 2. Styloid process view showing right elongated and calcified styloid process (arrow)(A). Coronal CT scan showing calcified stylohyoid ligament and pseudosarticulation between stylohyoid ligament and hyoid bone (arrow)(B).
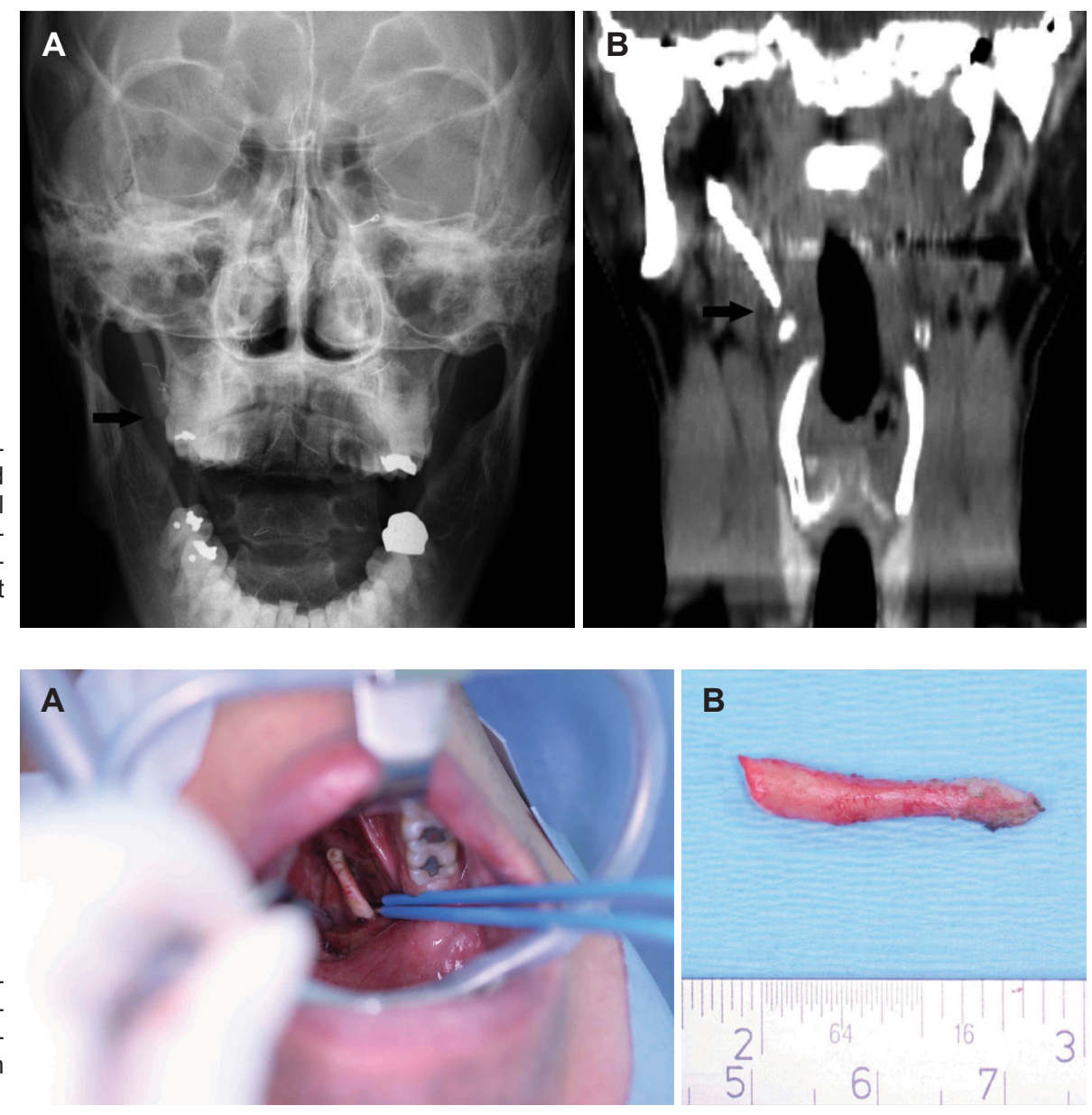

Fig. 3. After tonsillectomy, right elongated styloid process was dissected in the tonsillar fossa (A). Resected styloid process, measuring $2.5 \mathrm{~cm}$ in length $(B)$. 
골화 소견을 보였고 그 중 2명만이 인두 이물감, 연하곤란증 등의 증상을 호소하였다고 보고하였다. 반복되는 인후통, 인 두 이물감, 연하 곤란증, 편측에서 발생하는 이통, 경부 운동 에 따라 발생 또는 완화되는 경부 통증 및 관절음 등을 지속 적으로 호소하는 경우 이글 증후군과 비슷한 증상을 유발할 수 있는 다른 질환인 악관절 이상, 근막통, 치성 통증 등과의 감별도 반드시 필요하다. ${ }^{2)}$ 따라서 진단은 주로 임상양상과 이 학적 검사 및 영상학적 검사 등을 통해 결정이 된다. 컴퓨터단 층촬영이 구강 파노라마 촬영보다 경상돌기의 길이 및 각도, 경 상설골인대의 골화정도 등을 잘 보여 줄 수 있다. 특히 $3 \mathrm{D}-\mathrm{CT}$ 의 경우 경부 외상 환자에서 경상돌기, 경상설골인대, 설골의 3 차원적 관계와 골절부위를 보다 면밀히 파악할 수 있는 장점 이 있다. ${ }^{5)}$

본 증례 환자의 경우 사고 이전부터 우측 경상돌기의 골화 가 진행이 되어 경상돌기의 비대 및 연장이 있었으나 외상 이전 에는 무증상으로 지내고 있었다. 그러나 외상 후부터 우측으 로 경부 회전시 딸깍거리는 관절음이 발생하여 외상 후 발생 한 비전형적인 이글 증후군으로 추정할 수 있었다. 문헌 보고 에 의하면 관절음 발생의 기전을 골화된 경상설골인대의 굴곡 골절(greenstick fracture)과 경상설골인대가 설골의 소각과 부착된 부위의 가관절 형성(pseudoarticulation)으로 설명하 고 있다. ${ }^{6.7)}$ 본 증례의 경우는 경상설골인대의 골절이 영상학 적 검사에서 확인이 되지 않아서 오히려 경상설골인대와 설골 의 소각 사이의 가관절 형성으로 추정이 된다. 치료는 모두 경 상돌기를 절제하여 경상설골인대를 분리함으로써 병적 부위 를 감압하는 것이다. 본 증례에서도 경상설골인대를 경상돌기 로부터 분리하여 간접적으로 설골과 경상설골인대 부위의 불 완전 굴곡골절이 감압이 되는 효과를 가져와 수술 직후 환자 의 증상이 사라진 것으로 설명할 수 있다.

경부 및 인두의 관절음은 외상 후 이글 증후군에 의해 발생 하는 것 이외에도 이를 유발할 수 있는 요인으로 갑상연골과 설 골의 비정상적 비대 및 위치를 다른 문헌에서 보고하였다. ${ }^{89}$ Smith 등은 연하 혹은 경부 회전시에 발생하는 관절음을 호소하는 11 명을 대상으로 경부 $\mathrm{CT}$ 를 촬영한 결과 10 명의 환자에서 갑상연골의 상각이 후방으로 길어져 있거나 내측으 로 회전되어 있는 경우를 확인하여 이 부위를 절제함으로써 증상의 호전을 보였다고 보고하였다. 또한 다른 증례 보고에 서는 경부 회전시 클릭음이 발생하는 원인으로 설골의 대각 이 길어져서 경부 회전시에 척추와 마찰이 되어 발생한다고 보 고한 경우도 있었다."

이와 같이 환자가 호소하는 경부 및 인후부의 클릭음은 후두 골격을 구성하는 갑상연골, 설골, 경상돌기인대의 해부
학적 병인이 있는 경우가 대부분이기 때문에 정신병리적으 로 치부하여 환자의 삶의 질이 저하되는 것을 예방하여야 한 다. 이를 정확히 진단하기 위해서는 첫 번째로 면밀한 문진을 해야 하고 그 다음으로 환자가 호소하는 부위의 내시경 및 촉진을 통한 이학적 검사가 이루어져야 한다. 마지막으로 경부 $\mathrm{CT}$ 를 촬영하여 증상과 이학적 검사를 통해 이루어진 병소를 확인하여야 한다. 본 증례 환자의 경우에서도 클릭음을 유발 할 수 있는 다양한 원인을 고려하였고 문진을 통해 사고 직 후에 발생하였다는 것을 알 수 있었으며 우측 설골 부위에서 환자의 경부 회전시에 마찰음을 느낄 수 있었다. 이후 경부 CT 를 촬영하여 경상돌기 비대증을 확인하였으나 골화된 경상 설골 인대의 골절은 확인이 되지 않았다. 이런 경우에는 $3 \mathrm{D}-$ $\mathrm{CT}$ 를 촬영하는 것이 경상설골 복합체의 골절을 더 잘 파악 할 수 있을 것으로 사료된다. ${ }^{5)}$

본 증례와 같이 경부 외상 후 발생한 이글 증후군인 경우 초 기에는 경부 운동의 제한 및 경인두 스테로이드 및 국소마취 제 주입, 항우울제 및 진통제 투여와 같은 보존적 치료를 시행 할 수 있으나 보존적 치료에 증상 호전이 없는 경우에는 수술 적으로 경상돌기를 절제하여 경상설골인대를 감압함으로써 좋은 결과를 보일 수 있을 것으로 사료된다. 경부 접근을 하 여 절제할 수 있으나 미용적인 문제로 현재는 구강을 통한 절 제가 선호되지만 좁은 시야 등으로 수술시 경동맥의 손상을 가장 조심해야 한다. ${ }^{10)}$

\section{REFERENCES}

1) Eagle WW. Elongated styloid process; symptoms and treatment. AMA Arch Otolaryngol 1958;67(2):172-6.

2) Godden DR, Adam S, Woodwards RT. Eagle's syndrome: an unusual cause of a clicking jaw. Br Dent J 1999;186(10):489-90.

3) Prasad KC, Kamath MP, Reddy KJ, Raju K, Agarwal S. Elongated styloid process (Eagle's syndrome): a clinical study. J Oral Maxillofac Surg 2002;60(2):171-5.

4) Ilgüy M, Ilgüy D, Güler N, Bayirli G. Incidence of the type and calcification patterns in patients with elongated styloid process. $\mathrm{J}$ Int Med Res 2005;33(1):96-102.

5) Karam C, Koussa S. Eagle syndrome: the role of CT scan with 3D reconstructions. J Neuroradiol 2007;34(5):344-5.

6) Koivumäki A, Marinescu-Gava M, Järnstedt J, Sándor GK, Wolff J. Trauma induced eagle syndrome. Int J Oral Maxillofac Surg 2012;41(3):350-3.

7) Klécha A, Hafian H, Devauchelle B, Lefèvre B. A report of posttraumatic Eagle's Syndrome. Int J Oral Maxillofac Surg 2008;37 (10):970-2.

8) Smith ME, Berke GS, Gray SD, Dove H, Harnsberger R. Clicking in the throat: cinematic fiction or surgical fact? Arch Otolaryngol Head Neck Surg 2001;127(9):1129-31.

9) Hilali AS, Saleh HA, Hickery SA. Clicking hyoid. J R Soc Med 1997; 90(12):689-90.

10) Beder E, Ozgursoy OB, Karatayli Ozgursoy S. Current diagnosis and transoral surgical treatment of Eagle's syndrome. J Oral Maxillofac Surg 2005;63(12):1742-5. 